\title{
Epilactose production by 2 cellobiose 2-epimerases in natural milk
}

\author{
Manuel Krewinkel, Maria Gosch, Eva Rentschler, and Lutz Fischer ${ }^{1}$ \\ University of Hohenheim, Institute of Food Science and Biotechnology, Department of Biotechnology, Garbenstr. 25, 70599 Stuttgart, Germany
}

\begin{abstract}
It was reported recently that cellobiose 2-epimerases (CE) from various aerobic microorganisms convert lactose to epilactose in defined buffer systems. In this study, we showed that CE from 2 mesophilic microorganisms, Flavobacterium johnsoniae and Pedobacter heparinus, were capable of converting lactose to prebiotic epilactose not only in buffer but also in a complex milk system. First, the 2 enzymes were separately cloned, recombinantly expressed in Escherichia coli, and purified by column chromatography. The production of $F$. johnsoniae $\mathrm{CE}$ was carried out in a stirred-tank reactor, indicating that future upscaling is possible. The bioconversions of milk lactose were carried out at an industrially relevant low temperature of $8^{\circ} \mathrm{C}$ to avoid undesired microbial contaminations or chemical side reactions. Both enzymes were reasonably active at this low temperature, because of their origin from mesophilic organisms. The enzymes showed different operational stabilities over a 24-h time-course. A conversion yield of about 30 to $33 \%$ epilactose was achieved with both enzymes. No side products were detected other than epilactose. Therefore, CE may introduce an added value for particular dairy products by in situ production of the prebiotic sugar epilactose.
\end{abstract}

Key words: milk, cellobiose 2-epimerase, epilactose, prebiotic

\section{INTRODUCTION}

Lactose (4-o- $\beta$-D-galactopyranosyl-D-glucose) is a main component of cow milk, with an average content of 4.5 to $4.9 \%$ (wt/vol) (Thomasow, 1983). Ultra-hightemperature treatment of milk leads to the isomerization of lactose to 0.02 to $0.25 \mathrm{~g} / \mathrm{L}$ lactulose (4-o- $\beta$-Dgalactosyl-D-fructose) and 0.01 to $0.03 \mathrm{~g} / \mathrm{L}$ epilactose (4-o- $\beta$-D-galactosyl-D-mannose; Olano et al., 1989). The conversions are considered to proceed by the Lobry de Bryun-Alberda van Ekenstein transformation, including general acid-base catalysis and enolization

Received August 20, 2013.

Accepted September 14, 2013.

${ }^{1}$ Corresponding author: Lutz.Fischer@uni-hohenheim.de
(Speck, 1958; Mu et al., 2013). Both lactulose (Petuely, 1957; Ruttloff et al., 1967) and epilactose (Watanabe et al., 2008) possess prebiotic properties, as these disaccharides reach the lower gastrointestinal tract of the host and stimulate the growth of bifidobacteria. The value of milk or milk products may be enhanced by the enzymatic conversion of lactose to epilactose using cellobiose 2-epimerases (CE; EC 5.1.3.11; Watanabe et al., 2008). Microbial CE activity was first observed in Ruminococcus albus ATCC 27210 culture broth (Tyler and Leatherwood, 1967). The enzyme mediates mainly epimerization at $\mathrm{C} 2$ of the reducing end of $\beta$-1,4-linked oligosaccharides (Ito et al., 2007), such as the conversion of cellobiose (Glc-Glc) to 4-o- $\beta$-D-glucosyl-Dmannose (Glc-Man) and the epimerization of lactose (Gal-Glc) to epilactose (Gal-Man). It is suggested that the epimerization is catalyzed by a "triplet histidine center" (Fujiwara et al., 2013). No further substrates or cofactors are required. The physiological function of $\mathrm{CE}$ is unclear, but it is probably involved in the metabolic mechanism of mannan. In the mannan pathway, it epimerizes 4-o- $\beta$-D-mannobiose (Man-Man) to 4-o- $\beta$-Dmannosyl-D-glucose (Man-Glc) for further metabolism (Kawahara et al., 2012). The enzyme is prevalent in aerobic (Ojima et al., 2013) and anaerobic bacteria (Taguchi et al., 2008; Senoura et al., 2009; Park et al., 2011; Kim et al., 2012). The thermophilic CE from Caldicellulosiruptor saccharolyticus (Kim and Oh, 2012) and Dictyoglomus turgidum catalyze the epimerization of lactose to epilactose and the isomerization of lactose to lactulose (Gal-Fru; Kim et al., 2012). The epimerization reaction to epilactose has only been described for mesophilic CE to date (Ito et al., 2008; Taguchi et al., 2008; Ojima et al., 2013). Mesophilic enzymes with suitable activities at low temperatures (below $15^{\circ} \mathrm{C}$ ) are more suitable for application in milk than thermophilic enzymes, which possess their activities only at higher temperatures because the temperature of industrial milk processing is 4 to $10^{\circ} \mathrm{C}$.

Our investigations focused on the true application of mesophilic $\mathrm{CE}$ in original milk. Therefore, $2 \mathrm{CE}$, one each from mesophilic Flavobacterium johnsoniae DSM 2064 and Pedobacter heparinus DSM 2366, were recombinantly produced and the conversion of lactose to epilactose in cow milk was performed and analyzed. 


\section{MATERIALS AND METHODS}

\section{Chemicals and Enzymes}

All chemicals were of analytical grade or higher and supplied from Sigma-Aldrich (St. Louis, MO), Carl Roth (Karlsruhe, Germany), or Merck (Darmstadt, Germany). The T4 DNA ligase was purchased from Fisher Scientific (Schwerte, Germany), and restriction enzymes and polymerase were purchased from New England Biolabs (Ipswich, MA).

\section{Microorganisms, Plasmids, and Culture Conditions}

The genomic DNA sequences of Flavobacterium johnsoniae DSM 2064 and Pedobacter heparinus DSM 2064 $\mathrm{CE}$ were obtained from the European Molecular Biology Laboratory-European Bioinformatics Institute (Hinxton, UK; ENA Association No. ABQ07955 and ACU06174). The strains Escherichia coli XL-1 Blue, E. coli BL21 (DE3), and E. coli Rosetta-gami were used for cloning and expression. Plasmid pET-20b (+) was used as an expression vector, resulting in the constructs pET-20bFJCE and pET-20bPHCE, respectively. The recombinant cells were propagated in $200 \mathrm{~mL}$ of 2-yeast-tryptone (2YT) medium containing $10 \mathrm{~g} / \mathrm{L}$ yeast extract, $16 \mathrm{~g} / \mathrm{L}$ tryptone, $1 \%$ (wt/vol) glucose, $100 \mu \mathrm{g} / \mathrm{mL}$ ampicillin, and an additional $25 \mu \mathrm{g} / \mathrm{mL}$ chloramphenicol for the E. coli Rosetta-gami strain, in 1-L baffled shaking flasks at $37^{\circ} \mathrm{C}$. An amount of $0.5 \mathrm{~m} M$ isopropyl $\beta$-D-1-thiogalactopyranoside (IPTG) was added at an optical density at $600 \mathrm{~nm}\left(\mathrm{OD}_{600}\right)$ of 0.6 to induce expression. Cultivation was continued at $20^{\circ} \mathrm{C}$ for $22 \mathrm{~h}$. Additionally, E. coli BL21 (DE3) pET$20 \mathrm{~b} F J C E$ was cultivated in $800 \mathrm{~mL}$ of $2 \mathrm{YT}$ medium with $1 \%$ (wt/vol) glucose and $100 \mu \mathrm{g} / \mathrm{mL}$ ampicillin in a 1-L stirred-tank reactor (STR; Infors AG, Bottmingen, Switzerland) at $20^{\circ} \mathrm{C}$. Induction of expression was carried out by adding $0.5 \mathrm{mM}$ IPTG at an $\mathrm{OD}_{600}$ of 6 and the cultivation was continued for $30 \mathrm{~h}$.

\section{Gene Cloning of CE}

The CE genes from $F$. johnsoniae and $P$. heparinus were optimized for expression in E. coli using Gene Designer (DNA2.0 Inc., Menlo Park, CA). Moreover, NdeI and XhoI restriction sites were added before synthesis by Life Technologies (Darmstadt, Germany). The synthetic genes were subcloned into pET-20b $(+)$ to introduce a hexahistidine $\left(\mathrm{His}_{6}\right) \mathrm{tag}$ and transformed in E. coli XL-1 Blue. The resultant plasmids pET-20bFJCE and pET-20bPHCE were transformed in E. coli BL21 (DE3) and E. coli Rosetta-gami for expression, respectively.

\section{Protein Quantification}

Determination of protein concentrations was carried out by the Bradford method with BSA as standard (Bradford, 1976). Sodium dodecyl sulfate-PAGE, utilizing gels consisting of a $12.5 \%$ (wt/vol) acrylamide separation gel with a $6 \%(\mathrm{wt} / \mathrm{vol})$ acrylamide stacking gel, was used to monitor protein expression and evaluate the quality of protein purification (Laemmli, 1970). Bands were visualized by Coomassie Brilliant Blue R-250 staining, according to the Fairbanks method (Wong et al., 2000). The protein molecular mass standard (2 to $212 \mathrm{kDa}$ ) was obtained from New England Biolabs (Ipswich, MA).

\section{Purification of CE}

Recombinant cells were harvested by centrifugation at $8,000 \times g$ for 20 min at $4{ }^{\circ} \mathrm{C}$, washed twice with $0.9 \%$ (wt/vol) $\mathrm{NaCl}$, and resuspended in $50 \mathrm{~m} M$ sodium phosphate buffer, $\mathrm{pH} 7.0$, to obtain a $20 \%$ (wt/vol) cell suspension. The resuspended cells were disrupted on ice by sonication. Cell debris was removed by centrifugation at $8,000 \times g$ for $20 \mathrm{~min}$ at $4^{\circ} \mathrm{C}$. After passing the supernatant through a $0.45-\mu \mathrm{m}$ filter, the raw extract was purified by immobilized metal affinity chromatography, utilizing a Äkta system (GE Healthcare, Little Chalfont, UK) and a 12-mL Ni-IDA column (BioRad, Hercules, CA) equilibrated with loading buffer $(50 \mathrm{mM}$ sodium phosphate buffer, $\mathrm{pH} 7.0$, containing $20 \mathrm{mM}$ imidazole). The $\mathrm{CE}$ was eluted with a linear gradient from 20 to $500 \mathrm{mM}$ imidazole over 4 column volumes at a flow rate of $1 \mathrm{~mL} / \mathrm{min}$. The active fractions were collected and passed through a PD-10 desalting column (GE Healthcare) to remove imidazole via size exclusion chromatography (SEC), following the manufacturer's instructions. An amount of $50 \mathrm{mM}$ sodium phosphate buffer, $\mathrm{pH}$ 7.0, was used as an eluent for standard assays. A successive buffer exchange step was performed for the application of $\mathrm{CE}$ in milk using $10 \mathrm{~m} M$ sodium phosphate buffer, $\mathrm{pH}$ 7.0, as an eluent.

\section{Enzyme Assay}

The standard enzyme assay was carried out in a reaction volume of $200 \mu \mathrm{L}$. The reaction mixture contained $50 \mathrm{~g} / \mathrm{L}$ lactose in $50 \mathrm{~m} M$ sodium phosphate buffer, $\mathrm{pH}$ $7.0(100 \mu \mathrm{L})$ and suitably diluted enzyme in $50 \mathrm{mM}$ sodium phosphate buffer, pH $7.0(100 \mu \mathrm{L})$. The reaction was carried out at $37^{\circ} \mathrm{C}$ for $10 \mathrm{~min}$ and stopped by the addition of $400 \mu \mathrm{L}$ of $1 \mathrm{M} \mathrm{HClO}_{4}$.

The enzyme solution for the bioconversion in milk was not prepared in $50 \mathrm{~m} M$ sodium phosphate buffer, but in $10 \mathrm{~m} M$ sodium phosphate buffer, $\mathrm{pH}$ 7.0. There- 
fore, the assay conditions were also adapted to $10 \mathrm{mM}$ sodium phosphate buffer.

An amount of $50 \mu \mathrm{L}$ sample of the bioconversion was mixed with $150 \mu \mathrm{L}$ of $50 \mathrm{~g} / \mathrm{L}$ lactose in $10 \mathrm{mM}$ sodium phosphate buffer ( $\mathrm{pH} 7.0$ ) and incubated for $30 \mathrm{~min}$ at $37^{\circ} \mathrm{C}$ for a stability measurement. These assays were followed by HPLC analysis to determine the concentration of the reaction products.

\section{Biotransformation in Milk and Enzyme Stability}

Biotransformation was carried out in UHT milk containing $1.5 \%$ fat (Schwarzwälder UHT-Weidemilch $1.5 \%$, Schwarzwaldmilch GmbH, Freiburg, Germany; obtained from a local supermarket) using a thermostatcontrolled STR with a $25-\mathrm{mL}$ working volume at $8^{\circ} \mathrm{C}$ for $24 \mathrm{~h}$. Initial CE activity was 199 nanokatals (nkat) for $F j \mathrm{CE}$ and 352 nkat for $P h \mathrm{CE}$, respectively. Therefore, $2.5 \mathrm{~mL}$ of enzyme solution of the activity mentioned was added to the reaction vessel. All experiments were carried out in duplicate in 2 separate STR. Enzyme solution was replaced by buffer without enzyme in a third vessel for a negative control. Samples of $1 \mathrm{~mL}$ each were taken for the quantification of sugars and measurement of enzyme activity.

\section{Analytical Methods}

An HPLC system (Thermo Scientific Spectra System SCM1000, Waltham, MA) with a refractive index detector (Thermo Scientific Spectra System RI-150) was used to determine the concentrations of lactose and epilactose. Measurements were carried out at $50^{\circ} \mathrm{C}$ and with 3 carbohydrate Ca columns (CS Chromatographieservice, Langerwehe, Germany) at $85^{\circ} \mathrm{C}$. The mobile phase was double-distilled water $(0.6 \mathrm{~mL} / \mathrm{min})$. The sample preparation was adapted from Erich et al. (2012). An amount of $400 \mu \mathrm{L}$ of $1 \mathrm{M} \mathrm{HClO}_{4}$ was added, followed by centrifugation $(2 \mathrm{~min}, 20,000 \times g)$ to stop the enzymatic reaction. An amount of $500 \mu \mathrm{L}$ of the supernatant was mixed with an appropriate volume of $2 M \mathrm{KOH}$ to reach neutral $\mathrm{pH}$, and double-distilled water was added to a final volume of $5 \mathrm{~mL}$. After a 20-min incubation on ice, the samples were passed through a $0.45-\mu \mathrm{m}$ filter for direct HPLC analysis.

\section{Statistics and Replication of Experiments}

All enzymatic assays and analytic measurements were performed in duplicate. Data are expressed as means \pm standard deviation. Statistical analyses, calculation, and visualization were carried out using Sigma Plot 12 (Systat Software, San Jose, CA) or Excel (Microsoft Corp., Redmond, WA)
RESULTS

\section{Production of CE}

Wild-type $F$. johnsoniae and P. heparinus were cultivated in complex media for $\mathrm{CE}$ production (data not shown), and no CE activity was detectable. Similar results were obtained with Ruminococcus albus, wherein only very low activities of $\mathrm{CE}$ could be measured (Ito et al., 2007). Thus, E. coli was used as the host for recombinant production of the putative CE from F. johnsoniae and $P$. heparinus. The vector systems developed contained the synthetic $\mathrm{CE}$ genes and additional C-terminal hexahistidine tags. The template gene sequences resulted in the same AA sequences described by Ojima et al. (2013). The expression experiments were carried out in baffled shaking flasks. The overexpression of a $43-\mathrm{kDa}$ protein in the crude protein extract was observed after the expression of FjCE in E. coli BL21 (DE3). The expression of PhCE failed in E. coli BL21 (DE3). However, an expression protein band in the crude protein extract, thinner than that for $F j \mathrm{CE}$, was observed at $42 \mathrm{kDa}$ when utilizing $E$. coli Rosetta-gami as an expression host (Figure 1, lane 1). The theoretically calculated mass for $F j \mathrm{CE}$ protein was $47 \mathrm{kDa}$ and that for $P h \mathrm{CE}$ protein was $46 \mathrm{kDa}$.

The production of $F j \mathrm{CE}$ was also investigated on a larger scale using a STR. Here, a total protein yield of $4.15 \mathrm{~g}$ and a total CE activity of 1.14 kat was measured after cell disruption of the E. coli BL21 (DE3) pET20bFJCE. This CE activity corresponded to $1.48 \mathrm{~g}$ of $F j \mathrm{CE}$, which represented about 35\% (wt/wt) of the total soluble cell protein content.

\section{Purification of CE}

Both CE were separately purified to homogeneity via a single affinity chromatography step (Figure 1) and the $\mathrm{CE}$ activities were confirmed by standard assay (with lactose as substrate). After purification, the imidazole-containing buffer of the enzyme solutions was exchanged with the assay buffer by SEC. Purification results for $F j \mathrm{CE}$ and for $P h \mathrm{CE}$ are shown in Table 1. The degree of purification, overall yield, and specific activity were 2.5 -fold, $100 \%$, and 979 nkat $/ \mathrm{mg}$, respectively, for FjCE, and 4.0-fold, 39\%, and $301 \mathrm{nkat} / \mathrm{mg}$, respectively, for $P h \mathrm{CE}$.

The molecular sizes by SDS-PAGE (43 kDa for $F j \mathrm{CE}$ and $42 \mathrm{kDa}$ for PhCE; see Figure 1) were similar to those reported for the $\mathrm{CE}$ of Ruminococcus albus (43 kDa; Ito et al., 2007), Eubacterium cellulosolvens (47 kDa; Taguchi et al., 2008), and Bacteroides fragilis (41 kDa; Senoura et al., 2009). 
Table 1. Purification chart of Flavobacterium johnsoniae cellobiose 2-epimerase (CE) and Pedobacter heparinus $\mathrm{CE}$

\begin{tabular}{|c|c|c|c|c|c|c|}
\hline \multirow[b]{2}{*}{ Item $^{1}$} & \multirow{2}{*}{$\begin{array}{l}\text { Volume } \\
\text { (mL) }\end{array}$} & \multirow{2}{*}{$\begin{array}{l}\text { Total protein } \\
(\mathrm{mg})\end{array}$} & \multicolumn{3}{|c|}{ Enzyme activity data } & \multirow{2}{*}{$\begin{array}{l}\text { Purification } \\
\text { factor }\end{array}$} \\
\hline & & & $(\mu \mathrm{kat} / \mathrm{L})$ & (nkat/mg) & Yield (\%) & \\
\hline \multicolumn{7}{|l|}{ F. johnsoniae } \\
\hline Crude extract & 2.5 & 48.9 & 7,767 & 397 & 100 & 1.0 \\
\hline IMAC & 5.0 & 24.8 & 4,849 & 976 & 125 & 2.5 \\
\hline SEC & 7.0 & 19.9 & 2,787 & 979 & 100 & 2.5 \\
\hline \multicolumn{7}{|l|}{ P. heparinus } \\
\hline Crude extract & 2.4 & 28.7 & 908 & 76 & 100 & 1.0 \\
\hline IMAC & 5.0 & 3.7 & 377 & 510 & 86 & 6.7 \\
\hline SEC & 6.9 & 2.8 & 125 & 301 & 39 & 4.0 \\
\hline
\end{tabular}

${ }^{1} \mathrm{IMAC}=$ immobilized metal affinity chromatography; SEC = size exclusion chromatography.

\section{In Situ Production of Epilactose Using FjCE and PhCE}

Both purified CE (199 nkat for FjCE; 352 nkat for $P h \mathrm{CE})$ were investigated for epilactose production in milk under the same reaction conditions. Each biotransformation was carried out independently in duplicate. The process parameters were chosen with respect to a later upscaling under industrially relevant conditions. The biotransformations were performed in commercial UHT milk at $8^{\circ} \mathrm{C}$, a typical temperature for milk pro-

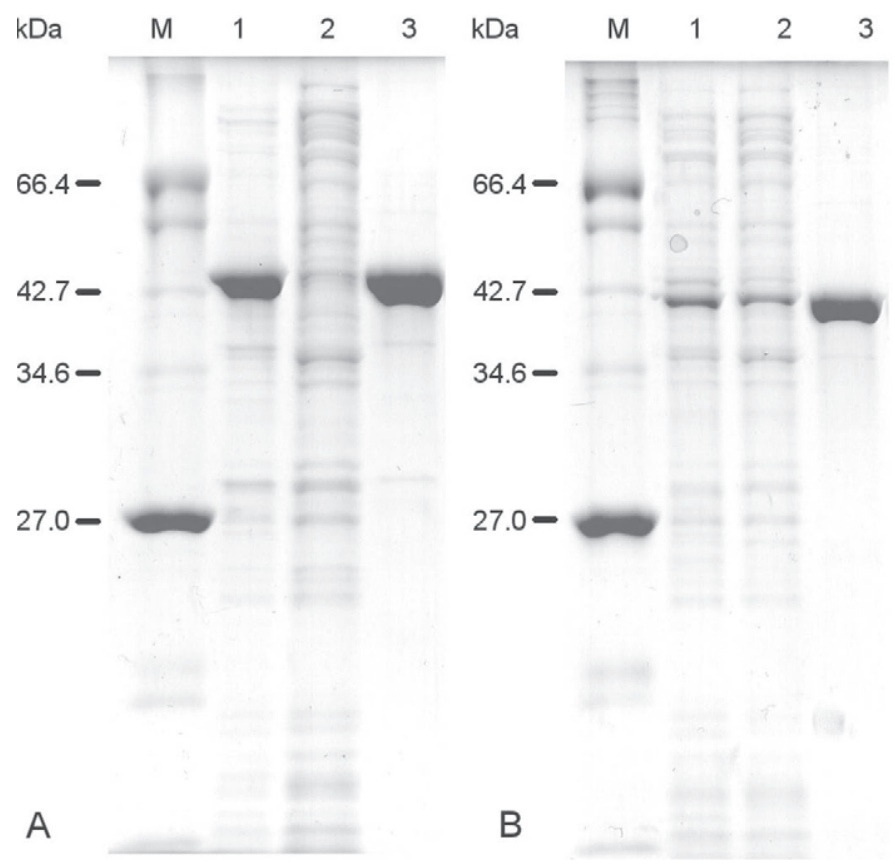

Figure 1. Sodium dodecyl sulfate-PAGE of cellobiose 2-epimerase (CE) fractions from (A) Flavobacterium johnsoniae, and (B) Pedobacter heparinus. Lane $\mathrm{M}=$ molecular mass marker; lane $1=\mathrm{CP}$ solution after cell disruption; lane $2=$ flow-through fraction of immobilized metal affinity chromatography (IMAC); lane $3=$ CE-active fraction after IMAC and desalting by size exclusion chromatography. cessing in the dairy industry. The mean values of these biotransformations are shown in Figure 2.

The biotransformation with $F j \mathrm{CE}$ (Figure 2A) resulted in $14.3 \mathrm{~g} / \mathrm{L}$ epilactose (33.6\% yield) after $24 \mathrm{~h}$. For $P h \mathrm{CE}$ (Figure 2B), a final epilactose concentration of $13.9 \mathrm{~g} / \mathrm{L}$ was obtained (30.5\% yield). Thus, the biotransformations with $F j \mathrm{CE}$ and $P h \mathrm{CE}$ showed similar results concerning final product yields. The specific initial epimerization rate of both bioconversions was different: from $24.5 \mathrm{mg}$ of epilactose/(L.h.nkat) for FjCE to $19.5 \mathrm{mg}$ of epilactose/(L.h.nkat) for PhCE. The activities of $\mathrm{CE}$ were controlled during the biotransformations (Figure 3). Both enzymes were active throughout the process time. The FjCE showed $31 \%$ and the $P h \mathrm{CE} 61 \%$ residual activity after $24 \mathrm{~h}$.

\section{DISCUSSION}

Previous studies on CE from mesophilic organisms report the substrate and product spectrum of this enzyme class (Ojima et al., 2013). In those studies, the applicability of $\mathrm{CE}$ for small-scale sugar production in biochemical buffer systems was shown. Preliminary qualitative experiments (thin-layer chromatography analysis) in milk were carried out in the case of the Ruminococcus albus CE (Watanabe et al., 2008). The quantitative results of our present study established in situ production of epilactose by $\mathrm{CE}$ in natural milk.

The production of recombinant $F j \mathrm{CE}$ was realized on a 1-L bioreactor scale, indicating the possibility for a later upscaling. The $F j \mathrm{CE}$ yield of $1.86 \mathrm{mg} / \mathrm{mL}$ was 5 times higher than that reported $(352 \mu \mathrm{g} / \mathrm{mL})$ by Ojima et al. (2013).

The expression systems E. coli BL21 (DE3) and E. coli Rosetta-gami, in combination with the pET-20b vector ( $\mathrm{pET}$ ) system providing the hexahistidine tag, were suitable for $\mathrm{CE}$ production and allowed fast and easy purification of the CE. With respect to later utilization of these enzymes in food technology, expression in antibiotic-free food-grade systems seems indispens- 
A

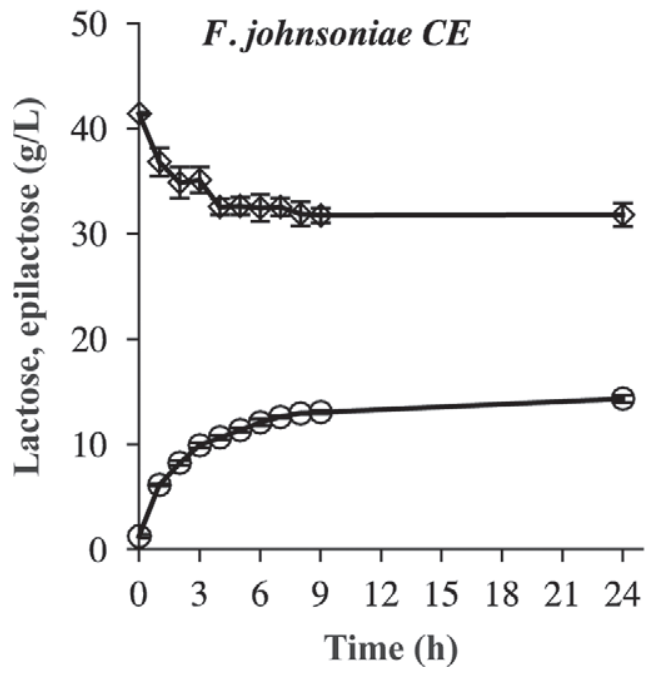

B

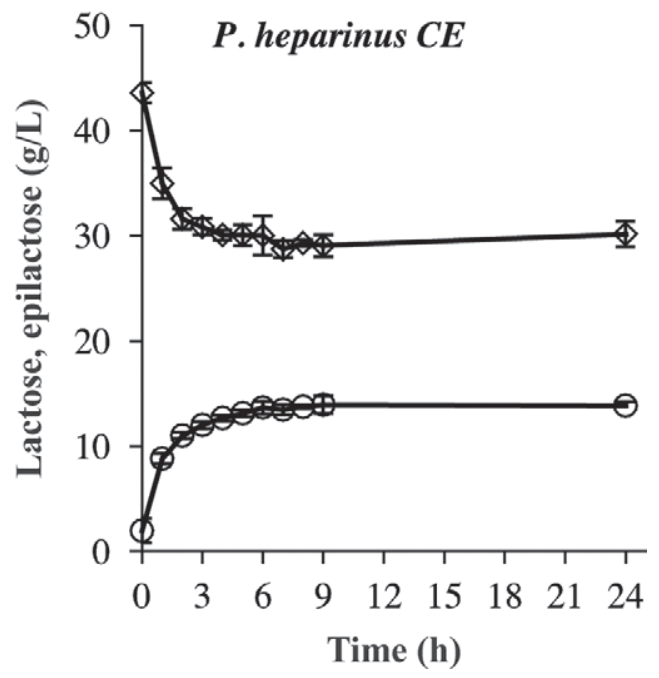

Figure 2. Time course of epilactose production in milk by (A) Flavobacterium johnsoniae cellobiose 2-epimerase (CE) and (B) Pedobacter heparinus $\mathrm{CE} . \diamond=$ lactose; $\bigcirc=$ epilactose.

able. Native expression of $\mathrm{CE}$ in wild-type strains was inapplicable because of absent or extremely low expression levels (Ito et al., 2007). Tag-free expression and purification of $F j \mathrm{CE}$ and $P h \mathrm{CE}$ have also been shown (Ojima et al., 2013).

The biotransformations were carried out at $8^{\circ} \mathrm{C}$, which is a typical storage and process temperature for milk. The enzymes FjCE and PhCE both originate from mesophilic organisms. The growth optimum of $F$. johnsoniae is about $30^{\circ} \mathrm{C}$ and that of $P$. heparinus is about $28^{\circ} \mathrm{C}$, respectively, indicating that the intracel- lular enzymes should have their temperature optima at mesophilic temperatures. Both enzymes showed the maximum activity in milk at about $37^{\circ} \mathrm{C}$ (data not shown), which was in accordance with the optimum in a biochemical buffer system at $35^{\circ} \mathrm{C}$ (Ojima et al., 2013). About 5.5\% (FjCE) and $15.9 \%$ (PhCE) of the maximum enzyme activity was preserved at the process temperature of $8^{\circ} \mathrm{C}$. Nevertheless, these activities seem suitable for bioconversion of lactose to equilibrium epilactose after $10 \mathrm{~h}$, using $8 \mathrm{nkat} / \mathrm{mL}$ for FjCE and $14 \mathrm{nkat} / \mathrm{mL}$ for $\mathrm{PhCE}$. Generally, bioconversions are
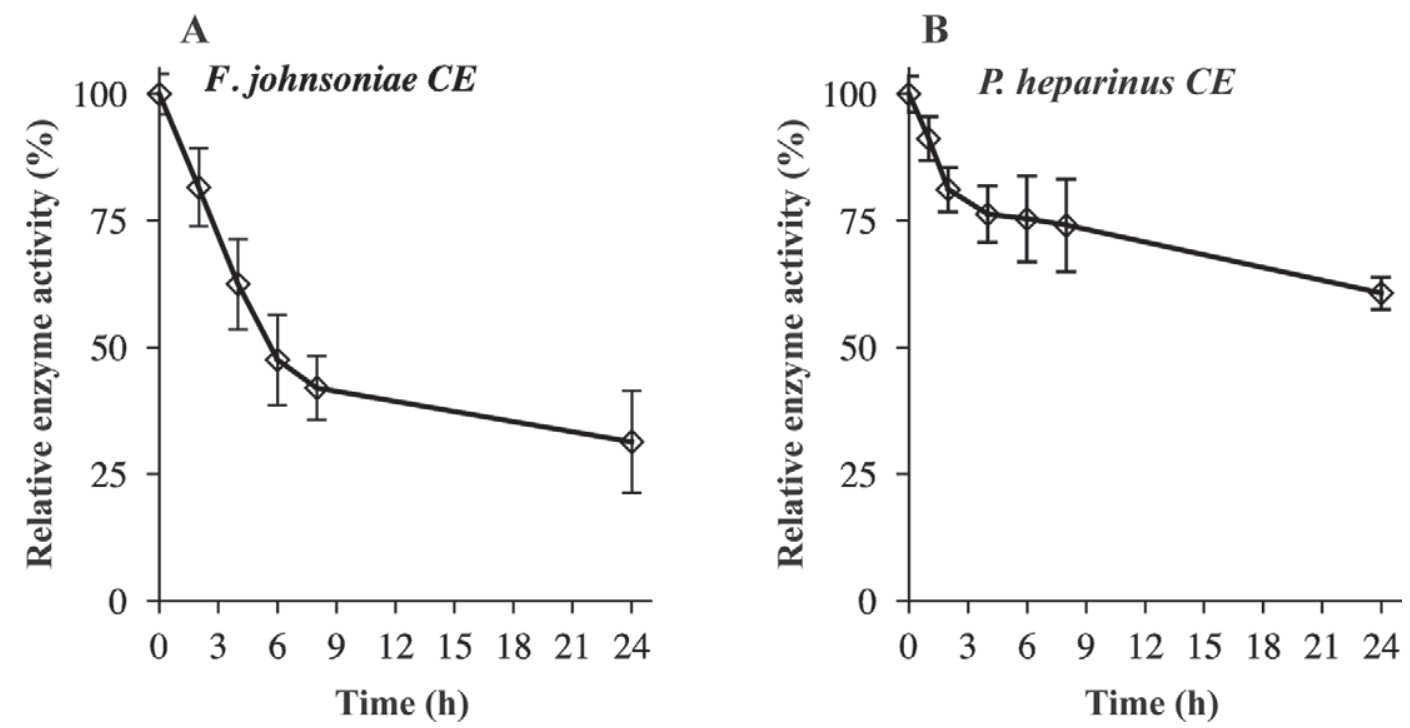

Figure 3. Activity performance of (A) Flavobacterium johnsoniae cellobiose 2-epimerase (CE; 100\% = 98.5 nkat $/ \mathrm{mL})$ and (B) Pedobacter heparinus $\mathrm{CE}(100 \%=352.4$ nkat $/ \mathrm{mL})$ during biotransformation with milk. 
not carried out at the enzyme's biochemical temperature optimum but at temperature approximately $10^{\circ} \mathrm{C}$ lower, where the operational stability (reaction velocity and inactivation rate) is higher.

The initial lactose concentrations of the biotransformations were slightly lower than in the commercial UHT milk (48 g/L lactose) because of dilution of the milk with the pure enzyme sample (10\% vol/vol). This resulted in an initial lactose concentration of about $43 \mathrm{~g} / \mathrm{L}$. Both enzymes produced about $14 \mathrm{~g} / \mathrm{L}$ epilactose at equilibrium, leading to a mean conversion yield of 30.5 to $33.6 \%$, which is in accordance with values reported in the literature. Saburi et al. (2010) showed an approximately $27 \%$ conversion yield in a bioconversion carried out by Ruminococcus albus CE. This biotransformation was performed at room temperature in $15 \mathrm{~L}$ of sodium phosphate buffer containing $3 \mathrm{~kg}$ of lactose monohydrate for $48 \mathrm{~h}$ (Saburi et al., 2010). In another bioconversion in a biochemical sodium phosphate buffer system, a conversion yield of about $30 \%$ epilactose was reached by $R$. albus CE ( $R m$ CE; Sato et al., 2012). This reaction was carried out with an immobilized CE at $50^{\circ} \mathrm{C}$ for $10 \mathrm{~d}$.

Both biotransformations with $F j \mathrm{CE}$ and $P h \mathrm{CE}$ were carried out for $24 \mathrm{~h}$ and had already reached equilibrium conditions with constant substrate and product concentrations after approximately $9 \mathrm{~h}$. Nevertheless, the performance of $F j \mathrm{CE}$ and $P h \mathrm{CE}$ differed, probably because of their different biochemical properties and the different initial enzyme activities applied. The Michaelis constant $\left(K_{m}\right)$ values of $F j \mathrm{CE}$ and $P h \mathrm{CE}$ reported, for example, by Ojima et al. (2013) were 34.9 and $24.5 \mathrm{~m} M$, respectively.

Both enzymes showed reasonable residual activity after $24 \mathrm{~h}$ (Figure 3), indicating that the initial enzyme activity chosen was high enough to ensure that the enzyme was active over the total reaction time. Nevertheless, residual activities after $24 \mathrm{~h}$ at $8^{\circ} \mathrm{C}$ were surprisingly low compared with other mesophilic enzymes. A stabilizing formulation might be recommended for a later industrial application.

The industrial application of enzymatic epilactose production is interesting because of the properties of this disaccharide compared with lactose. As reported by Watanabe et al. (2008), epilactose showed a bifidogenic effect similar to lactulose in animal models. Lactulose is currently produced in thermochemical processes that include separation and purification steps to remove undesired by-products (Adamczak et al., 2009). This is necessary because alkaline or complex reagents such as aluminate and borate, which are toxic, are used (Lee et al., 2004). Chemical synthesis of epilactose is also possible but, due to several reaction steps, is very complicated (Mu et al., 2013). In contrast, the reaction mixture of the enzymatic process presented here contained only epilactose and lactose and no further byproducts. After successfully demonstrating the direct conversion of milk lactose under reaction parameters typically used for milk processing in the dairy industry, the development of further processes, such as using whey, seems conceivable. Thus, the utilization of CE in the dairy industry opens up new perspectives for a generation of products with potential prebiotic properties.

\section{REFERENCES}

Adamczak, M., D. Charubin, and W. Bednarski. 2009. Influence of reaction medium composition on enzymatic synthesis of galactooligosaccharides and lactulose from lactose concentrates prepared from whey permeate. Chem. Pap. 63:111-116.

Bradford, M. M. 1976. A rapid and sensitive method for the quantitation of microgram quantities of protein utilizing the principle of protein-dye binding. Anal. Biochem. 72:248-254.

Erich, S., T. Anzmann, and L. Fischer. 2012. Quantification of lactose using ion-pair RP-HPLC during enzymatic lactose hydrolysis of skim milk. Food Chem. 135:2393-2396.

Fujiwara, T., W. Saburi, S. Inoue, H. Mori, H. Matsui, I. Tanaka, and M. Yao. 2013. Crystal structure of Ruminococcus albus cellobiose 2-epimerase: Structural insights into epimerization of unmodified sugar. FEBS Lett. 587:840-846.

Ito, S., S. Hamada, K. Yamaguchi, S. Umene, H. Ito, H. Matsui, T. Ozawa, H. Taguchi, J. Watanabe, J. Wasaki, and S. Ito. 2007. Cloning and sequencing of the cellobiose 2-epimerase gene from an obligatory anaerobe, Ruminococcus albus. Biochem. Biophys. Res. Commun. 360:640-645.

Ito, S., H. Taguchi, S. Hamada, S. Kawauchi, H. Ito, T. Senoura, J. Watanabe, M. Nishimukai, S. Ito, and H. Matsui. 2008. Enzymatic properties of cellobiose 2-epimerase from Ruminococcus albus and the synthesis of rare oligosaccharides by the enzyme. Appl. Microbiol. Biotechnol. 79:433-441.

Kawahara, R., W. Saburi, R. Odaka, H. Taguchi, S. Ito, H. Mori, and H. Matsui. 2012. Metabolic mechanism of mannan in a ruminal bacterium, Ruminococcus albus, involving two mannoside phosphorylases and cellobiose 2-epimerase: Discovery of a new carbohydrate phosphorylase, beta-1,4-mannooligosaccharide phosphorylase. J. Biol. Chem. 287:42389-42399.

Kim, J. E., Y. S. Kim, L. W. Kang, and D. K. Oh. 2012. Characterization of a recombinant cellobiose 2-epimerase from Dictyoglomus turgidum that epimerizes and isomerizes $\beta-1,4$ - and $\alpha-1,4$-glucooligosaccharides. Biotechnol. Lett. 34:2061-2068.

Kim, Y. S., and D. Oh. 2012. Lactulose production from lactose as a single substrate by a thermostable cellobiose 2-epimerase from Caldicellulosiruptor saccharolyticus. Bioresour. Technol. 104:668672.

Laemmli, U. K. 1970. Cleavage of structural proteins during the assembly of the head of bacteriophage T4. Nature 227:680-685.

Lee, Y. J., C. S. Kim, and D. K. Oh. 2004. Lactulose production by $\beta$-galactosidase in permeabilized cells of Kluyveromyces lactis. Appl. Microbiol. Biotechnol. 64:787-793.

Mu, W., Q. Li, C. Fan, C. Zhou, and B. Jiang. 2013. Recent advances on physiological functions and biotechnological production of epilactose. Appl. Microbiol. Biotechnol. 97:1821-1827.

Ojima, T., W. Saburi, T. Yamamoto, H. Mori, and H. Matsui. 2013. Identification and characterization of cellobiose 2-epimerases from various aerobes. Biosci. Biotechnol. Biochem. 77:189-193.

Olano, A., M. M. Calvo, and N. Corzo. 1989. Changes in the carbohydrate fraction of milk during heating processes. Food Chem. 31:259-265.

Park, C. S., J. E. Kim, J. G. Choi, and D. K. Oh. 2011. Characterization of a recombinant cellobiose 2-epimerase from Caldicellulosiruptor saccharolyticus and its application in the production of mannose from glucose. Appl. Microbiol. Biotechnol. 92:11871196. 
Petuely, F. 1957. The Lactobacillus bifidus factor. Dtsch. Med. Wochenschr. 82:1957-1960.

Ruttloff, H., A. Täufel, W. Krause, H. Haenel, and K. Täufel. 1967. Die intestinal-enzymatische Spaltung von Galakto-Oligosacchariden im Darm von Tier und Mensch mit besonderer Berücksichtigung von Lactobacillus bifidus 2. Mitt. zum intestinalen Verhalten der Lactulose. Nahrung 11:39-46.

Saburi, W., T. Yamamoto, H. Taguchi, S. Hamada, and H. Matsui. 2010. Practical preparation of epilactose produced with cellobiose 2-epimerase from Ruminococcus albus NE1. Biosci. Biotechnol. Biochem. 74:1736-1737.

Sato, H., W. Saburi, T. Ojima, H. Taguchi, H. Mori, and H. Matsui. 2012. Immobilization of a thermostable cellobiose 2-epimerase from Rhodothermus marinus JCM9785 and continuous production of epilactose. Biosci. Biotechnol. Biochem. 76:1584-1587.

Senoura, T., H. Taguchi, S. Ito, S. Hamada, H. Matsui, S. Fukiya, A. Yokota, J. Watanabe, J. Wasaki, and S. Ito. 2009. Identification of the cellobiose 2-epimerase gene in the genome of Bacteroides fragilis NCTC 9343. Biosci. Biotechnol. Biochem. 73:400-406.
Speck, J. C. 1958. The Lobry de Bruyn-Alberda van Ekenstein transformation. Adv. Carbohydr. Chem. 13:63-103.

Taguchi, H., T. Senoura, S. Hamada, H. Matsui, Y. Kobayashi, J. Watanabe, J. Wasaki, and S. Ito. 2008. Cloning and sequencing of the gene for cellobiose 2-epimerase from a ruminal strain of Eubacterium cellulosolvens. FEMS Microbiol. Lett. 287:34-40.

Thomasow, J. 1983 Chemische und physikalische Aspekte zur pasteurisierten Konsummilch. Pages 114-138 in Die Mich. H. O. Gravert, ed. Ulmer, Stuttgart, Germany.

Tyler, T. R., and J. M. Leatherwood. 1967. Epimerization of disaccharides by enzyme preparations from Ruminococcus albus. Arch. Biochem. Biophys. 119:363-367.

Watanabe, J., M. Nishimukai, H. Taguchi, T. Senoura, S. Hamada, H. Matsui, T. Yamamoto, J. Wasaki, H. Hara, and S. Ito. 2008. Prebiotic properties of epilactose. J. Dairy Sci. 91:4518-4526.

Wong, C., S. Sridhara, J. C. Bardwell, and U. Jakob. 2000. Heating greatly speeds Coomassie blue staining and destaining. Biotechniques 28:426-428, 430, 432 . 